\title{
A Review on Advances in Pruning to Vegetable Crops
}

\author{
Omesh Thakur*, Vijay Kumar and Jitendra Singh \\ Department of Vegetable Science, Indira Gandhi Krishi Vishwavidyalaya, Raipur, \\ Chhattisgarh-492012, India \\ *Corresponding author
}

\begin{tabular}{|c|c|}
\hline & A B S T R A C T \\
\hline $\begin{array}{l}\text { Ke y w o r d s } \\
\text { Pruning, Vegetable } \\
\text { crops, Growth, } \\
\text { Development, } \\
\text { Quality }\end{array}$ & \multirow{3}{*}{$\begin{array}{l}\text { Vegetables are important constituents of Indian agriculture and nutritional security due to } \\
\text { their short duration, high yield, nutritional richness, economic viability and ability to } \\
\text { generate on-farm and off-farm employment. Our country is blessed with diverse agro- } \\
\text { climates with distinct seasons, making it possible to grow wide array of vegetables. } \\
\text { Pruning can encourage faster growth of new shoots, which has the potential to bloom. } \\
\text { Training and Pruning technique deserve attention in yield and quality enhancement of } \\
\text { vegetable crops. Through its effect on improved photosynthetic efficiency, plant growth, } \\
\text { and optimization of vegetative and reproductive balance. A few research works has been } \\
\text { conducted on this aspect to improve the growth, yield and quality of vegetable crops. The } \\
\text { literature available on pruning in vegetable crops are collected under the following heads } \\
\text { (1) Response of pruning on the vegetative growth and yield (2) Response of pruning on } \\
\text { quality characters (3) Economic studies. }\end{array}$} \\
\hline Article Info & \\
\hline $\begin{array}{l}\text { Accepted: } \\
\text { 28 January } 2018 \\
\text { Available Online: } \\
\text { 10 February } 2018\end{array}$ & \\
\hline
\end{tabular}

\section{Introduction}

Pruning is the removal of plant parts.

These are typically shoots or branches, but sometimes buds, flowers, fruit or roots are removed as well.

\section{Objective of pruning}

To remove the non-productive parts in order to divert the energy into those parts that is capable of bearing fruits. Maintain the proper proportion of root: shoot ratio.

Better quality of fruits by better light penetration.
Dry matter distribution is primarily regulated by the sink-strength of the various organs. When the available assimilates equal or exceed the total sink strength of the plant, the growth rates of the vegetative parts and the individual fruit or clusters occur at the potential rates. However, when the amount of available assimilates is less than the total sink strength, the assimilates are distributed between leaves, stem, roots and fruit according to their individual sink strengths relative to the total sink strength.

The sink strength of an organ can be quantified by the potential growth rate of a sink, that is, the growth rate under conditions of non-limiting assimilate supply. Fruit 
pruning is used to control fruit load; fruit load influences partition between vegetative and generative plant growth and fruit size through mutual competition for assimilates between fruit (De Koning, 1996). Truss pruning serves an important role in maximising DM partitioning to the fruit, while maximising marketable yield. The main reasons for leaf pruning are to reduce disease pressure, accelerate fruit ripening and make harvesting easier (Heuvelink et al., 2005). Leaf pruning could be used to reduce vegetative sink strength and increase biomass partitioning to the fruit (Xiao et al., 2004).

Response of pruning on the vegetative growth and yield of vegetable crops

\section{Tomato}

Knott (1928) found that tipping (removal of the apical bud) of tomato plants delayed maturity 6 days, and leaf pruning. Patil et al., (1973) reported that tomato plant can be severely pruned without affecting the yield in tomato.

Tanaka and Fujita (1974) studying sourcesink distribution in tomato, observed that photosynthates flow from sources exceeds sink demands and that the partial removal of tomato leaves is compensated with an increase in the net assimilation rate of the remaining leaves; thus, fruit growth is unaffected. Similar results were reported by Starck (1983). Rajewar and Patil (1979) observed that pruning increases costs in plants production and improves light penetration inside the plant canopy and increases photosynthesis efficiency and fruit yield.

Nganga (1984) found in his experiment that pruning resulted in a higher flower-fruit ratio in general, and it is suggested that a higher fruit: leaf ratio achieved on fewer leaves through pruning may enhance fruit yield production in a plant. Pruning controls carbon partition and thus affects the ratio and hence fruitfulness in tomato (Resh, 1997).

Baki (1987) reported that pruning showed a significant effect on plant height in tomato. Unpruned plants exhibited higher plant height and highest number of inflouresence. Higher number of fresh ripe fruits were also obtained from unpruned plants. But maximum yield of tomato (96.08 tonn per ha) was obtained from the pruned ones with 2 stems at the closest spacing $(75 \times 75 \mathrm{~cm})$. Hernandez and Sanches (1992) found that fruit length of tomato was greatest in plants for pruning one stem and the number of fruits was higher.

Davis and Estes (1993) stated that pruning of tomato plants could reduce production costs, increase yields and improve the quality of fruits. Early season yields were higher using early pruning (when lateral shoots were 5-10 $\mathrm{cm}$ long) or delayed pruning (when lateral shoots were $30-36 \mathrm{~cm}$ long) in tomato. Heuvelink and Buiskool (1995) stressed that assimilate translocation in a tomato plants to the fruit strongly depends on the number of fruit (sinks) per truss. They reported that a reduction in fruit number resulted in an increase in fruit size. Rubatzky (1996) reported that pruning allows for some regulation of fruit size and flowering. Fruit size can be improved by removing the axillary shoots and regulating the number of fruits per cluster. The light utilization in the canopy is not limited by much foliage which reduces shading, and thus the supply of assimilates to all the fruits is sufficient to sustain the growth of the majority of fruits. Pruning helps to control the amount of light reaching each plant and allows for better ventilation around each plant. It also keeps a better balance with the root system and usually produces larger fruit than if the plant is allowed to grow into a bush (Opena et al., 1985). Myint (1999), who indicated that the two stem pruning method 
gave the highest marketable yield compared to single stem and non-pruned plants of indeterminate tomato cultivars. Pruning facilitates insecticide spraying and harvesting (AVRDC, 1999) thus increasing the number of marketable fruits in pruned plants.

Arzani et al., (2000) found that fruits, as powerful sink for carbohydrates, growth till end of the growing season and increase of volume depend on fruit number. Gautier et al., (2001) found that pruning of tomato increased the mean dry mass of stems and petioles (up to 43 per cent) and lamina (up to 22 per cent) along with an increase in mean dry mass of fruit (up to 42 per cent). Thus, helps in maintaining an optimum balance between partitioning to the harvestable organs (fruit) and other plant parts (vegetative).

Xiao et al., (2004) found that early leaf pruning increased DM partitioning to the fruit from 57 to $61 \%$. However in both cases pruning treatments reduced total yield compared to the non-pruned control because of a reduced LAI which reduced net biomass production in tomato. Kanyomeka and Shivute (2005) reported that pruning had no significant effect on tomato yield. The only benefits obtained from tomato pruning were increased quality and plant health. Pruned tomatoes were less prone to pest attack than those, which were not pruned.

Preece and Read (2005) observed that the effect of pruning on quantitative and qualitative characteristics of tomato showed that pruning limits vegetative growth and allows more light penetration and so improves qualitative and quantitative characteristics of tomato fruits. Heuvelink et al., (2005) found that by delaying pruning of old leaves and increasing the LAI from 3 to 4 , yield was increased by $40 \%$. But beyond a LAI of 4 , there was little change in gross photosynthesis and maintenance respiration, suggesting that growers should prune their plants to ensure a LAI of no more than 4 in tomato. McGraw et al., (2007) indicated that pruning small basal branches helps to maintain the balance between vegetative and reproductive biomass in tomato.

\section{Cassava}

Larson (1975) reported that shoot and root pruning before transplanting allows seedlings to establish roots first before transpirational demands begin which is important for reducing transplanting stress in cassava. Hunt et al., (1977) asserted that deposition of starch in storage roots can be reduced if the supply from the top is interrupted as occurs when much of the leaf and stem materials are removed in cassava.

Richard and Rowe (1977) suggested that root pruning while reducing shoot growth, stimulates root growth as the plants attempt to restore the pre-pruning shoot: root ratio. Rajewar and Patil (1979) observed that pruning increases costs in plants production and improves light penetration inside the plant canopy and increases photosynthesis efficiency and fruit yield. Santiago (1980) reported that topping at 60-90 DAP reduced yields significantly in cassava while Arana (1979) reported an increased yield with pruning at $60 \mathrm{DAP}$ in cassava.

Villamayor and Labayan (1982) found that a single pruning of $20 \mathrm{~cm}$ shoot length or longer at 3 months after planting (MAP) significantly reduced the yields in cassava. Abenoja and Cerna (1983) found that removing the upper $30 \mathrm{~cm}$ of the shoots at 4 , 6 , and 8 weeks intervals, starting at 4, 5 or 6 MAP did not affect root yield in cassava.

Villamayor et al., (1992) reported that cassava plants pruned at $30 \mathrm{~cm}$ above ground at 6 th, 8th or 10th MAP resulted significantly 
higher tuber yield than unpruned plants as well as those pruned at 2nd or 3rd month after planting. Tung et al., (2001) reported possible decline in storage root yield as a result of intensive pruning in cassava.

Aguiar et al., (2011) in a study conducted in Brazil indicated that pruning at monthly intervals during September to April in two seasons did not affect the dry matter content and root yield of cassava when harvested after 22 months. Sunitha et al., (2015) reported that control treatment without any pruning resulted in maximum tuber yield of cassava, however, it was on par with single pruning, at $3^{\text {rd }}$ month. Two prunings at $3^{\text {rd }}$ and $6^{\text {th }}$ months reduced the tuber yield significantly. It was evident that excessive pruning results in reduced tuber yield whereas a single pruning during the active vegetative phase of the crop, i.e., during $3^{\text {rd }}$ month can regain the vegetative growth. However, second pruning towards the end, at $6^{\text {th }}$ month resulted in the set back of active photosynthesis and translocation of photosynthate to the roots. All the varieties used were of short duration and were harvested 7 MAP. The growth of unpruned plants was never disturbed and produced maximum storage roots, whereas, the pruned ones had to recover by producing new stems and leaves. This reduced carbohydrate available for storage roots. However, single pruning did not affect the tuber yield significantly indicating that the plants could recover the physiological activity and thus contributing for storage of roots in cassava.

\section{Onion}

Hawthorn (1938) found no advantage in either root or top pruning of Bermuda onion plants. Maiti and Sen (1968) reported that partial pruning of seedling at the time of transplanting augmented the start of onion and increase the size of bulb.
Nahar (2007) evaluated the effect of pruning and irrigation intervals on growth and yield of onion. The experiment included 3 pruning treatment: (i) Control (no pruning), (ii) root pruning and (iii) leaf and root pruning and five frequencies of irrigation interval of 5, 10, 15, 20 and 25 days. The yield and yield components varied significantly with pruning and different irrigation intervals. The highest yield of bulb per hectare (8.67 ton) were produced from the plants under leaf and root pruning treatment. The highest bulb yield of (10.36 ton $\left.\mathrm{ha}^{-1}\right)$ was recorded from irrigation at 5 days from root pruning with irrigation at 25 days interval. Leaf and root pruning with irrigation at 5 days intervals gave the maximum net return and benefit cost ratio.

Honjo et al., (2016) investigated the effects of leaf- and root-pruning treatment of cell seedlings at planting time on plant growth, nitrogen uptake, harvest time, and yield in Japanese bunching onion (Allium fistulosum L.). Leaf-pruning treatment had a negative effect on the number of living leaves and leaf sheath diameter, which were inhibited until harvest however, although the number of roots and root growth were temporarily inhibited, the growth was equal to that of the control. Root-pruning treatment negatively affected the number of emergent leaves, plant height, number of living leaves, shoot weight, leaf sheath diameter, number of roots, and growth of roots until harvest on August 20. The total amount of nitrogen uptake was lower in the root-pruning treatment than that in the leaf-pruning treatment.

\section{Okra and brinjal}

Kabir (2010) found that pruning delayed fruiting in okra and usually gave more larger and desirable percentage of good quality fruits. Hence pruning facilitates opening of leaves to sunlight and partitioning of assimilates was high in pruned plants. 
Lipari (1981) reported that pruning increases fruit quality and yield in eggplants. Pruning to balance the number of shoots and leaves causes an increase in flowers and fruits. Pruning at every node two fruit set was recommended for higher yield with good quality of eggplants (Shehtata, 2012). Ambroszczyk et al., (2008) reported in brinjal that plants pruned to two shoots, second shoot led out from the sixth node produced the greatest fruits, both in early and total yield. Fruits of two shoot plants with the second shoot led out from the sixth node and pruned to one shoot contained the greatest level of ascorbic acid.

The greatest levels of reducing sugar and starch were found in the leaves of moderately pruned plants, having the best PAR conditions. The method of pruning slightly affected the level of pigments in the eggplant leaves. Pruning at the every node two fruit set up was recommended for higher yield and good quality of eggplant.

\section{Sweet peppers}

Resh (1996) reported that the pruning of peppers cultivated in a greenhouse improves light interception, fruit set and fruit quality due to the reduced number of branches. Jovicich et al., (1999) reported higher marketable yields from sweet pepper plants pruned to four stems, compared to those pruned to two or one stem. In general, no or light pruning results in excessive vegetative growth of plants with small fruit size. Bhatt and Rao (1997) indicated that removal of the fruit in the first flowering node of bell pepper plants ten days after fruit set did not increase the partitioning of dry mass to fruit on upper nodes of the plant. With the advancement of fruit growth, the first flowering node fruit acts as a major sink for photosynthates $(10.2 \%)$ up to 20 days after flowering, and afterwards becomes a weaker sink.

\section{Cucurbits}

Gobeil and Gosselin (1989) conducted an experiment on the influence of pruning season of cucumber. They reported that summer pruning gave a high production of fruits.

Arora and Malik (1989) reported that pruning of ridge gourd plants to six primary branches with a medium spacing level $(45 \mathrm{~cm})$ produced the longest plants, gave maximum number of secondary branches, resulted in early appearance of pistillate flowers, lowered sex ratio and gave higher number and weight of fruits from early and total yield.

The result of reduced sex ratio for pruning was due to more production of secondary branches on which pistillate flowers appeared in large number.

Thang (1995) reported that the treatments of the experiment were No pinching (M0), Pinching branches on main stem at node 10 up to down (Mi), Pinching branches on main stem at node 15 up to down (M2), No pruning (P0) and pruning branches at node 4 The method of pruning branches had no significant effect on horticultural character such as fruit size and plant height. The pinching treatments had low yield.

This was resulted because of the absence of sufficient branches in cucumber. $\mathrm{Nu}$ (1996) stated that the effect of pruning (pinching out the branches on main stem at node 4 up to the bottom and prune when lateral shoots on main stem set fruit on first on second node of lateral shoot) on yield and fruit quality Duong (1999) reported that pruning had no effect on the length of the fruits and mean fruit weight. Pruned cucumber had higher weight of fruits than the unpruned ones. Palada and Chang (2003) found that the removal of the lateral shoots had a positive effect on the total yield of bitter gourd. 


\section{Carrot}

Umbel pruning and umbel order are important factors for the quality of carrot seed (Pereira et al., 2008 and Amjad et al., 2005). Umbel pruning is done mainly for balancing and influencing the nutrients and hormones. As a result of umbel pruning the existing umbels face less competition for nutrients and hormones. More nutrients and hormones are transported to the flowers and they produce bigger, heavier and healthy seeds.

\section{Effect of pruning on quality character in vegetable crops}

Watson (1947) stated that total dry matter of a crop is the output of net photosynthesis. It is mainly dependent on the size of photosynthesis system or its activity as well as the length of its growth period during which photosynthesis continues. Evans (1972) stated that photosynthesis is the main contributing factor for increasing in plant dry matter.

Data et al., (1984) reported that except for polyphenol oxidase (PPO) activity, and crude fiber, sugar and moisture content, cassava roots harvested from unpruned plants exhibited higher respiration rate, phenyl alanine ammonia-lyase (PAL) activity, and starch, HCN and dry matter content than roots from pruned plants at harvest. The ratings for quality attributes in terms of texture, flavor and general acceptability were lower in roots harvested from unpruned than pruned cassava plants, while the reverse was true in color and appearance. Regardless of days of storage, respiration rate, weight loss, vascular streaking, decay, PAL activity and dry matter content were higher in roots harvested from unpruned plant than pruned plants. Respiration rate, weight loss, vascular streaking, decay, PAL and PPO activities, sugar and crude fiber content of cassava roots increased with storage time. Starch content and ratings for all quality attributes decreased, while HCN content increased earlier and decreased later during storage in cassava.

Tanaka et al., (1984) explained that the effect of pruning treatment in retarding physiological deterioration in cassava roots may be partly based on the toughening of the cellular structure of the root tissue not only the outer but also the inner part, thus reducing mechanical injury at harvest and during handling. Another reason may be due to some unknown physiological alterations in the cellular structure that maintain the cellular activity at a lower level and delay physiological deterioration. Tung et al., (2001) reported possible decline in storage root yield as a result of intensive pruning of cassava. This is because defoliation reduces root weight due to reduced carbohydrates synthesized per plant and hence reduced quantity of photoassimilates available for storage in cassava.

Ayoola and Agboola (2004) observed reduction in yield and mean storage root weight when cassava plants were pruned irrespective of the pruning method. The reduction in storage root sizes in the pruned plants could be explained by the fact that as the plants were pruned, photosynthates that should have been used for storage root bulking were used for regrowth of new shoots. This, therefore, resulted in smaller storage roots due to reduced carbohydrates available for storage root bulking possibly due to reduced carbohydrates synthesized per plant and hence reduced quantity of food available for storage.

Sunitha et al., (2015) explained that the growth of unpruned plants was never disturbed which produced maximum storage roots, whereas, the pruned ones had to recover by producing new stems and leaves. This 
reduced carbohydrate available for storage roots. However, single pruning did not affect the tuber yield significantly indicating that the plants could recover the physiological activity and thus contributing for storage of roots in cassava. Kanyomeka and Shivutte (2005) found that increase of fruit quality on account of weak pruning can be due to more assimilate production by leaves. In pruning light penetrate into the canopy, low leaf area decreases photosynthesis rate. Therefore, in double branch or pyramidal pruning there is an appropriate proportion between leaves and light penetration into the canopy so nutrient content on the fruits would be increased.

Therefore it is concluded that pruning method is beneficial to the farmers for higher production and quality vegetable production and also therefore it is recommended that vegetable grower farmers should adopt pruning practices to obtain higher marketable yields that will fetch them good prices. However it is imperative to gain sound knowledge of training and pruning in vegetable crop with a careful consideration of suitable training and pruning methods, intensity, growth stages and crop season in respect of a particular vegetable crop in order to obtain the desired yield and quality attributes.

\section{References}

AbdelAl, Z. E., Mirghani, H. B., Abusin, A. and Percy, P. 1962. The effect of pruning and training on the yield of tomato cultivars grown for export in the Sudan. ISHS. Acta. Hortic., 33: 30-33.

Abenoja, E. A. and Cerna, A. F. 1983. The effect of age and frequency of topping in cassava on quality of shoots, dry matter and tuber yield. The Radix, 5(1): 12- 13.

Aguiar, and Eduardo Barreto. 2011. Pruning dates and productivity of cassava. Pesq. agropec. bras., [online]., 46 (11): 14631470.
Ambroszczyk, A. M., Cebula, S. and Sekara, A. 2008. The effect of plant pruning on the light conditions and vegetative development of eggplant (Solanum melongena L.) in greenhouse cultivation. Veg. Crops Res Bull 68: 57-70.

Amiard V., Mueh, K.E., Demmig-Adams, B., Ebbert, V., Turgeon, R., Adams, W.W., 2005.Anatomical and photosynthetic acclimation to the light environment in species with different mechanisms of phloem loading. PNAS 102(36): 1296812973.

Arana, M. N. 1979. The effects of time of pruning on the yield of cassava (Golden yellow) B. S. thesis, DMMMSU, Bacnoten, Launion, p.14.

Arora, S. K. and I. J. Malik. 1989. Effect of pruning and spacing levels on growth, flowering, earliness and fruit yield in Ridge gourd. Haryana J. Hort. Sci. 18(12): 99-105.

Arzani, K., Lawes, G.S. and Wood, D.E.S.2000.Seasonal vegetative and fruit pattern of mature close planted apricot trees grown under humid climate. Acta hortic., 516:75-82.

Ayoola, O. T., \& Agboola, A. A. (2004). Influence of cassava planting patterns and pruning methods on crop yield in a cassava-based cropping system. Afr. Crop Sci. J., 12: 115-122.

Baki, A. 1987. Effects of spacing and pruning on the yield of tomato cultivar Oxheart. An MS thesis, Department of Horticulture, BAU, Mymensingh. P. 8.

Balibrea, M. A., Martinez-Andujar, C., Cuartero, J., Bolarin, M.C. and PérezAlfocea, F. 2006. The high fruit soluble sugar content in wild Lycopersicon species and their hybrids with cultivars depends on sucrose import during ripening rather than on sucrose metabolism. Funct. Plant Biol 33: 279288.

Bhatt, R. and Rao, N. 1997. Growth and photosynthesis in bell pepper as affected by sink manipulation. Biologia Plantarum, 39, 437-439. 
Burgis, D.S. and R.A. Levins. 1974. Pruning determinate tomato plants will increase dollar return. Proc. Florida State Hort. Soc. 87:122-124.

Carlton, W.M., Gleason, M.L. and Braun, E.J. 1994. Effects of pruning on tomato plants supporting epiphytic populations of Clavibacter michiganensis subsp. michiganensis. Plant Dis. 78:742-745.

Cebula, S. 1996. Effect of plants pruning on the growth, yields, and fruit quality of two cultivars of eggplant (Solanum melongena L.) in greenhouse production. Acta Agraria Silvestria/Agraria.34: 1-11.

Cebula, S. and Ambroszczyk, A.M. 2000. The influence of plant defoliation on growth, yielding and fruit quality of eggplant grown in a greenhouse. Roczn. AR Pozna, 323: 233-237.

Data, E.S. Quevedo, M.A. and Gloria, L.A.1984. Pruning techniques affecting the root quality of cassava at harvest and subsequent storage. AGRIS, FAO.Org.

Davis, J. M. and Ester, E.A. 1993. Spacing and pruning effect on growth, yield and economic returns of staked fresh market tomatoes. J. Soc. Hort. Sci., 118(6): 719725 .

De Koning, N.M., 1996. Model predictions of optimum shoot density and truss size in glasshouse tomato. Acta Hort. 417, 99106.

Duong, H. X.1999. Effect of pruning on yield and quality of cucumber. AVRDC Training Report, Kasetsart University, Bangkok, Thailand. p51.

Erickson, L.C.1945. Principles of Horticultural production. Amer. J. Bot., 32: 634-643.

Evans, G.C. 1972. The quantitative analysis of plant growth. Bell Well Scient. Publi. Oxford, p-34.

Gautier, H., Guichard, S. and chamitchan, M. 2001. Modulation of competition between fruit and leaves by flower pruning and water fogging, and consequences on tomato leaf and fruit growth. Annals of Botany, 88: 645-652.

Gobeil, G. and Goselin, A. 1989. The influence of pruning and season on fruit development in a crop of European cucumber. Can J. Plant Sci. 699 (3): 1037-1048.

Goda, Y., Abd El-Rehim, A.S., Mohamed, A.A., Helaly, A.A., and El-Zeiny, O.A.H. 2014. Effect of shoot Pruning on growth, yield and fruit quality of Husk Tomato (Physalis pubescens L.). Journal of American Science 10, 629-631.

Hawthorn, Ueslie R. 1938. Cultural experiments with yellow Bermuda onions under irrigation. Texas.।Fir. Fixpt. Sta. Bui. 561, 30 Pp., Illus.

Hernandez, C.V.M. and Sanches, F.C.D. 1992. Response to planting distance and pruningsystem in tomatoes growing in hydroponics culture in a basic green house. Deptt. of de Fifotecnia, Univerdad Aufonoma Chapingo. 15 (73-74):23-25.

Heuvelink, E. and Buiskool, R.P.M., 1995. Regulation of sink source interaction on dry matter production in tomato. Anal. Bot. 75, 381-389.

Heuvelink, E., Bakker, M.J., Elings, A., Kaarsemaker,R. and Marcelis, L.F.M., 2005. Effect of leaf area on tomato yield. Acta Hort. 691, 43-.50.

Honjo, M., Takeda, Satoru., Yoshida, Yasunori and Kaneta, Yoshihiro.2016.Effects of Leaf and root pruning at planting time on plant growth, Nitrogen uptake, harvest time, and yield in Japanese bunching onion (Allium fistulosum L.). Hort. Res. (Japan), 15(1): 11-17.

Hunt, I. A., Wholey, D.W., and Cock, J.H. 1977. Growth physiology of cassava (Manihot esculenta Crantz) field crops abstract 30: 77-91.

Jovicich, E., Cantliffe, D. J. and Hochmuth, G. J. 1999. Plant density and shoot pruning on yield and quality of a summer greenhouse sweet pepper crop in North central Florida. p. 184- 190. In K.D. Batal (ed.) 28th National Agricultural Plastics Congress. Proc. Amer. Soc. Plasticulture, Tallahassee, FL, May 19- 22. ASP, State College, PA.

Kabir, A. 2010. Effect of branch pruning on plant growth, fruit and seed yield in okra 
(Abelmoschus esculentus) cv. LD 661.Unpublished research project submitted to crop production Department, Federal University of Technology, Minna, Niger state, $18,562-568$.

Kanyomeka, L. and Shivute, B.2005.Influence of pruning on tomato production under controlled environments. Agricult. Trop. Subtrop, 38 (9):79-83.

Knott, J. F.1928.The effect of apical pruning of tomato seedlings on growth and early yield. Amer. Soc. Hort.Sci. Proc., 24: 2123.

Larson, M. 1975. Pruning northern red oak nursery seedlings: effects on root regeneration and early growth. Can. J. For. Res. 5(3): 381-386. Crossref.

Lipari, V.1981. Green pruning and auxin treatment of eggplants. Pataturaverde tratementi auxinci mellon melonzan. Culture protetti 10 (8/9): 39-44.

Maiti, S.C.and Sen, P.R.1968.Curr.Sc., 37:566568(cited from Bose, T.K. and Som, M.G.1990.Vegetable crops in India. Naya Prakash, 206 Bidhan Sarani, Calcutta, India).

McCraw, B.D. and Greig, J.K. 1986. Effect of transplant age and pruning procedure on yield and fruit-set of bell pepper. Hort. Sci., (21): 430-431.

Muhammad, A. and Singh, A. 2007. Yield of tomato as influenced by training and pruning in the Sudan Savanna of Nigeria. J. Plant Sci., 2(3): 310-317.

Myint, A. 1999. Effect of pruning and spacing on performance of fresh market tomato. AVRDC report. Kasestart University, Thailand. http:/www.arcavrdc.org.pdf=files/Myint Aung.pdf site visited on 20/06/2010.

Nahar, K.2007. Effects of pruning and irrigation on growth and yield of onion cv. N-53. M.S. Thesis, Department of Horticulture, Bangladesh Agricultural University, Mymensingh

$\mathrm{Nu}$ T.T.1996. Pruning effect on yield of different cucumber varieties, ARC Training Report, Nakhon Pathom, Thailand.
Opena, R.T. 1985. Development of tomato and Chinese cabbage adapted to the hot, humid tropics. Acta Hort. 178:624-635.

Palada, M.C. and Chang, L.C. 2003. Suggested cultural practices for bitter gourd. AVRDC. No. 3 pp547.

Patil, V. K., Gupta, P. K. and Tombre, P. O. 1973. Influence of pruning, mulching and nitrogenous fertilizer on the growth, yield and quality of staked plants of sioun variety of tomato, Punjab Vegetable Grower., 8: 4-9.

Pereira, R.S., Nascimento, W.M. and Vieira, J.V. 2008. Carrot seed germination and vigor in response to temperature and umble orders. Scientific Agricola, 65(2): 145-150.

Preece J.E. and Read, P.E. 2005. The Biology of Horticulture. 2th Ed. Copyright by John Wiley and Sons. New York, United States, 528 p.

Rafi, U.M., 1996. Stem pruning and spacing and spacing effect on the yield of tomato. AVRDC Training Report. Kasetsart University, Bangkok, Thailand: AVRDC, pp: 168-173.

Rajewar, S. R. and Patil V.K. 1979.Flowering and fruiting of some important varieties of tomato as affected by spacing, staking and pruning. Ind. J Agricult. Sci 49(5): 358-360.

Resh, H.M. 1997. Hydroponic Tomatoes for the Home Gardener. Published by Woodbridge Press Publishing Company. Calofornia.

Resh, H.M., 1996. Hydroponic food production, 5th edn, Woodridge Press Publ. Co., Santa Barbara, Califonia.

Richard, D. and Rowe, R.N. 1977.Root shoot interaction in peach. The function of the root. Annals of Botany, 49:1211-1216.

Rubatzky, V.E. 1996. World Vegetables: Principles, Production and Nutritive Values. Second Edition. Chapman and Hall, ITP International Thomson Publishing 115 Avenue. New York, USA. NY1003. 843p.

Santiago, C. C.1980. Response of cassava to topping and manuring under MMSU 
conditions. B.S. thesis, MMSU, Batac, Illocos, Norte, 39.

Shehata, S.A., El-Sayed, S.F. and Hasan, H.A. 2012. Effects of pruninf and spacing on the yield and quality of eggplants. J. Food Agric. Environ. 1(2):215-221.

Starck, Z. 1983. Photosynthesis and endogenous regulation of the source-sink relation in tomato plants. Photosynthetica 17: 1-11.

Sunitha, S., Ravindran, C.S., George James., Sreekumar, J.2015. Effect of pruning on cassava stem, foliage and tuber yield. Journal of Root Crops, 41(2): 36-41.

Tanaka, A. and K. Fujita. 1974. Nutriophysiological studies on the tomato plant. IV. Source-sink relationship and structure of the source-sink unit. Soil Sci. Plant Nutr. 20:305-315.

Tanaka, Y., Data. Emma. S., Lape, V., Villegas Cynthia. D., Gorgonio, Marieta. 1984. Effect of Pruning Treatment on Physiological Deterioration in Cassava Roots. Agric. Biol Chem., 48(3): 739743.

Thakur, M. C., Shyam, L. and Arun, J. 2005. Effect of different training systems and spacing on yield and quality characters and its impact on economics of tomato production. Hort., J. 18(1): 64-68.

Thang, D. X. 1995. Pruning Effect on yield of cucumber variety poung. ARC. Training Report, Nakhon Pathom, Thailand.

Tinni, T. B. R., Ali, M.A., Mehraj, H., Mutahera, S., and Uddin, A.F.M.2014. Effect of pruning technique on growth and yield of brinjal. J. Expt. Biosci., 5(1):
55-60.

Tung, C. M., Liang, J. B., Tan, S. L., Ong, H. K., \& Zelan, Z. A. 2001. Fodder productivity and growth persistency of three local cassava varieties. Asian-Aust. J. Anim. Sci, 14(9):1253-1259.

Valeton, B.1984.Effect of leaf and root pruning on the yield of bulbing onion (Philippines).AGRIS, 5(2):122-124.

Villamayor, S. G., Dingal, A. G., Evangelio, F. A., Ladera, J. C., Medellin, A. C., Sagise, G. E. and Burgos, G. B. 1992. Recent progress in cassava agronomy research in the Philippines In: Howler R H (Ed.) Cassava Breeding, Agronomy and utilization research in Asia. Proc. 3rd Regional Workshop, Malang, Indonesia, Oct. 22-27.1990, pp. 245-259.

Villamayor, S.G. and Labayan, A.L. 1982. Detopping and its effect on cassava production. The Radix, 4 (2): 7-8.

Watson, G.W. and Sydnor, D.T.1987.The effect of root pruning nursery trees. Journal of Arboriculture, 13:1-6.

Wurster, R. T. and Nganga, S. 1971. The effect of staking and pruning on the yield and quality of fresh market tomatoes in East Africa. Acta Hort. (ISHS), 21: 110-115.

Xiao, S., Van Der Ploeg, A., Bakker, M. \& Heuvelink, E., 2004. Two Instead of three leaves between tomato trusses: measured and simulated effects on partitioning and yield. Acta Hort. 654, 303-308.

\section{How to cite this article:}

Omesh Thakur, Vijay Kumar and Jitendra Singh. 2018. A Review on Advances in Pruning to Vegetable Crops. Int.J.Curr.Microbiol.App.Sci. 7(02): 3556-3565.

doi: https://doi.org/10.20546/ijcmas.2018.702.422 